\title{
Analysis of Factors Cause to Non-Optimal Management of Follow-up Audit Findings Case Study on Finance Education and Training Agency, Ministry of Finance
}

\author{
Nina Andriana \\ State Finance Polytechnic STAN, Indonesia
}

\begin{abstract}
This research aimed to analyze the factors that cause the management of audit findings to be not optimal, case study on Finance Education and Training Agency, Ministry of Finance. This research is a qualitative study using thematic analysis method. Research informants are officials and employees directly involved in managing the follow-up on audit findings. The results showed several factors that caused the management of audit findings not optimal yet, namely the factors of leadership commitment, human resources, communication, monitoring and evaluation, standard operating procedures, and enforcement of rules and integration of employee performance. Alternative solutions in optimizing the management of follow-up audit findings are through knowledge management and strengthening the role of the Internal Compliance Unit.
\end{abstract}

Keywords: Thematic analysis; causative factors; knowledge management; follow up on audit findings.

DOI: $10.7176 /$ RJFA/10-18-09

Publication date:September $30^{\text {th }} 2019$

\section{Introduction}

Law No. 17 of 2003 mandates that management of state finances needs to be carried out in a professional, open and accountable manner. Rai (2008) states that public sector organizations get the trust and confidence of the public to use public resources. Therefore, they are required to manage these resources accountably and transparently. To increase accountability and transparency in resource management, audits are needed in the public sector. The purpose of the public sector audit is emphasized in Law No. 15 of 2004 concerning the Audit of State Financial Management and Responsibility. This law states that audit function to support the success of efforts to manage state finances in an orderly and obedient manner in the applicable laws and regulations.

In an audit, both by an external auditor and an internal auditor, one of the results is an audit finding which is an indication of a discrepancy between the implementation of the budget and the existing provisions. The audit findings are material problems that are collected, processed and tested during carrying out audit tasks on the activities carried out by the auditee that are appropriate to be stated and communicated to the parties concerned (Rai, 2008). Concerning the audit findings, the auditee follows up on the findings recommendations.

Follow-up on the audit findings performed by the entity is a form of responsibility of the entity in making efforts to resolve the audit findings contained in the audit reports (LHP) by Audit Board of Republic of Indonesia (BPK), and for corrective action for the entity. In reality, in the period of examination of the financial statements of the Finance Education and Training Agency (FETA) from 2010 to 2017, there were still repeated audit findings, both related to the types of findings regarding internal control and compliance with statutory provisions, which indicated that the management of follow-up audit findings was still not optimal.

Therefore, it is expected that with this research, it can be seen what are the causes of the non-optimal management of follow-up audit findings in this case at FETA, as well as recommending solutions that can be done so that the follow-up of audit findings becomes more optimal which is further expected to improve the quality of state financial management. Based on the background above, the formulation of the issues that will be discussed in this study are:

1. What are the factors that cause the management of audit findings to be not optimal at FETA?

2. What is the solution that can be done to optimize the management of follow-up audit findings on FETA?

Based on the formulation of the problem above, the objectives of this study are as follows:

1. Identifying the factors that cause the management of audit findings has not been optimal in FETA.

2. Identifying solutions that can be done to optimize the management of follow-up audit findings at FETA.

\section{Review of Related Literature}

\subsection{Agency Theory}

According to Adams (1994), Agency Theory (agency theory) postulates that companies consist of contractual relations between economic resource owners (principals) and managers (agents) who are entrusted with the use and control of resources. Accountability in the context of the public sector is the responsibility, presentation of reports and disclosure of various activities and activities carried out by the government as the holder of the mandate 
to the public as the trust giver, who is entitled to obtain that responsibility. Based on agency theory, financial management in the public sector must be monitored to ensure that management is carried out in full compliance with various applicable laws and regulations. Examination which is the task of BPK includes examination of management and responsibilities regarding state finances.

\subsection{Examining Apparatus}

In article 6 of Law Number 15 Year 2006, the BPK's task is to examine the management and responsibilities of state finances carried out by the Central Government, Regional Governments, Other State Institutions, Bank Indonesia, BUMN, Public Service Agencies, BUMD, and other institutions or bodies which manages state finances. The auditor collects evidence to make conclusions about whether the financial statements have been adequately presented and to determine the effectiveness of internal control, after which new published audit reports are appropriate (Arens, Elder, and Beasley, 2008).

\subsection{Audit Findings}

According to Sawyer, Mortimer, and James (2005), audit findings are deviations from acceptable norms or criteria. Audit findings are important (material) problems that are found during the audit and these issues are appropriate to be raised and communicated with the audited entity because they have an impact on the improvement and enhancement of the economic performance, efficiency, and effectiveness of the audited entities (Rai, 2008 ). Audit findings include conditions, criteria, causes, effects, and recommendations (Hiro, 1997; Akmal, 2006, in Tri Hartono, 2006). Evidence that internal auditors find must be convincing, that is, the criteria must be accepted and there is confidence in the logic used. Likewise with the development of audit findings, if the findings developed are by following all audit standards, then the findings can be said to be logical, reasonable, and convincing, which will provide a stimulus to motivate corrective action (Sawyer, Mortimer, and James, 2005).

\subsection{Follow-up on Audit Findings}

According to John and Dwi (2009), the responsibility of the audited entity (auditee) is to follow up on recommendations for the creation and maintenance of a process and information system that can monitor the follow-up of the auditor's recommendations. Besides, the examiner needs to ensure that all lines of entity management know and monitor the results of inspections related to the units under his control. The monitoring is carried out by management and not only by the supervisor of the entity concerned (BPK, 2007). According to Sawyer, Mortimer, and James (2005), in general, remedial actions should be:

a. Responsive to reported weaknesses;

b. Complete in repairing all material aspects of existing weaknesses;

c. Its effectiveness is sustainable; and

d. Supervised as prevention to reoccur.

According Murwanto, Adi, and Dawn (2006), the objectives of the follow-up of the audit are:

a. Ensuring that the auditee has implemented recommendations on the audit findings contained by the Audit Report adequately and promptly,

b. Knowing the progress of follow-up suggestion/recommendation in the Audit Report which has not yet been completed,

c. Monitors the improvements that have been made by the entity (management), so that the results and their effects are known for the entity examined, and

d. Ensure that no findings are found in the previous audit of the audit being carried out.

\subsection{Public Sector Management Control Systems}

According to Murwanto, Adi, and Fajar (2006), the focus of public expectations on government organizations lies in the organization itself and the ability of organizational leaders to lead, in which the organization is articulated as governance and leadership as stewardship (management responsibility). The success of good governance must be supported by the completeness and confidence of information about the performance and consumption of resources used for public services, transparency, and high accountability. So that the main element of accountability is in the form of information availability or transparency (Murwanto, Adi, and Fajar, 2006). The law in the field of state finance has implications for the need for a more accountable and transparent state financial management system. This can only be achieved if all levels of leadership carry out control over all activities in their respective agencies.

In PP No. 60/2008 it is stated that the Internal Control System (SPI) is an integral process of actions and activities carried out continuously by the leadership and all employees to provide adequate confidence in the achievement of organizational goals through effective and efficient activities, reliability of financial reporting, securing state assets, and compliance with laws and regulations. Furthermore, to provide guidelines and benchmarks in testing the effectiveness of the implementation of SPI, the elements of SPI are developed as follows: 

a. Control environment.
b. Risk assessment.
c. Control activities.
d. Information and communication.
e. Monitoring.

\subsection{Knowledge Management}

Takeuchi and Ikujiro (2004) describe two types of knowledge namely tacit knowledge and explicit knowledge. Tacit knowledge is an understanding that is in the mind of the knowledge owner and cannot be directly raised in the form of data or knowledge representation so that it is often called unstructured knowledge. While explicit knowledge is knowledge that is directly in the form of knowledge and is generally referred to as structured knowledge. So, knowledge is a combination of the two knowledge. Takeuchi and Ikujiro (2004) offer four models of knowledge formation and transfer. This model is often called the SECI model (Socialization, Externalization, Combination, and Internalization).

Ulfiyati and Christiono (2015) also stated that knowledge management can help the process of problemsolving because knowledge management no longer requires a long time to find experts in solving problems. This is in line with the statement of Robles and Flores (2004) in Ohiorenoya and Ohimai (2014) that there is agreement both from the academic community and from the practitioner community, that knowledge management systems have a positive impact on organizational performance.

\subsection{Previous Research}

In Indonesia, several studies have been conducted related to follow-up on audit findings. In 2002 Baidowi conducted a follow-up analysis of the LHP with a case study at the Jombang District Supervisory Office. The results showed that the handling of cases that came in and was followed up from the examination report had not reached $90 \%-100 \%$ or not in the very good category. In 2006 Hartono researched on the completion of follow-up on audit findings as an element of branch office management performance evaluation (case study at Bank BTN). The results of the study indicate that the inclusion of completion of the follow-up of the results of the examination into a performance appraisal can be a driver of the completion of the follow-up of the results of the examination.

In 2010 Rahman analyzed the audit procedures for the procurement of goods and services in the Gorontalo provincial government, the results of which showed that the procurement of goods and services carried out by the procurement committee had been carried out in accordance with Presidential Decree Number 80 of 2003 and various amendments regarding the guidelines for procurement of government goods and services. Research also shows that the implementation of audit procedures for the procurement of goods and services carried out by the Gorontalo Provincial Inspectorate has not been able to help maintain the quality of work in the procurement of goods and services including helping to prevent potential losses to the region which amounted to $18.19 \%$ of the audited expenditure allocation.

Subsequently, in 2011, Ariawan conducted a study of the strength of the effectiveness of the recommendations in the follow-up to the results of BPK inspection in the Central Java Provincial. From the results of the study note that the implementation of BPK recommendations in the area of Central Java Province has not been fully carried out effectively and achieved optimal results. Legal steps that can be taken so that the recommendations of the BPK in the Central Java Province can have a force of law that is to strengthen the legal basis of the obligation to implement the recommendations of the BPK and cooperate with law enforcement officials who are authorized to carry out criminal action if a rule has been violated.

Furthermore, in 2012, Arini conducted a study of the role of managers in the audit findings follow-up by the Internal Investigation Unit at Sanglah Hospital Denpasar. The results of the study showed that the support, leadership, motivation, and communication of managers in all lines were not yet maximal, lack of non-financial compensation support, lack of facilities, and lack of guidelines for the unit to follow up caused the implementation of audit findings follow-up to be incompatible provisions.

\section{Research Methodology}

This study used a qualitative research approach with case study method on FETA. In general, case studies are the strategy of choice when the question "how" or "why" is raised, when the investigator has little control over events, and when the focus is on contemporary phenomena in several real-life contexts (Yin, 2003). The definition of qualitative research as synthesized by Moleong (2014) is research intended in the context of understanding the phenomena experienced by research subjects such as behavior, perception, motivation, actions, etc. holistically, described in the form of words and languages, in a special natural context and by utilizing various natural methods. The research problem will be described and analyzed in-depth through a qualitative approach, namely how to carry out the management of the follow-up of audit findings at FETA, then analysis will be carried out according to the internal control system in optimizing the management of the follow-up of audit findings. 
In collecting data, researchers used data in the form of primary data and secondary data. Primary data obtained by researchers in the form of first-hand information that is tailored to the specific objectives of the study. Secondary data refers to information collected from existing sources (Sekaran, 2003). Primary data collection was obtained through document studies, interviews, and participatory observation. Interviews were conducted with officials/employees within FETA who were directly involved in the process of managing the follow-up on audit findings, namely:

a. Sumiyati, Head of FETA;

b. Bambang July Istanto, Head of Division of Finance, Secretariat of The Agency;

c. Rachmat Effendi, Head of Subdivision of Accounting and Financial Reporting, Secretariat of The Agency;

d. Denny Handoyo Supriatman, Head of Division of General Affairs, currently acting as the Commitmet Making Officer (PPK) at Secretariat of The Agency;

e. Mulyadi, Head of the Subdivision of Assets Management, currently as the Procurement Officer at Secretariat of The Agency;

f. Mohammad Sandri Merizanta, Head of Financial Education and Training Hall Center Pontianak (as a Budget User), before 22 September 2014;

g. Agus Sunarya Sulaiman, Head of STAN Secretariat, before 2016;

h. Vitrie Rahmawati, Head of Subdivision of Planning and Finance, Tax Education and Training Center, before January 13, 2014;

i. Anwar, staff of Subdivision of Planning and Finance, Tax Education and Training Center; and

j. Sumawan, as the officials/organizers recipients of employment, STAN.

Also, interviews were conducted with officials at the Inspectorate General, Ministry of Finance, whom associated with this research, namely Mr. Ahmad Ghufron, Head of the Organization and Analysis of Supervision Results, as the person responsible for monitoring the follow up of audit findings within the scope of the Ministry of Finance. While secondary data for this study were obtained from publication data, archives, and documents related to the problem under study, such as the audit report conducting by BPK and reports of monitoring and evaluation.

Data analysis carried out includes three activities carried out simultaneously, namely (Miles and Huberman, 1984, in Sugiyono, 2010):

1. Data Reduction

According to Braun and Clarke (2006) in Solikhin (2014), data reduction can use thematic analysis, namely the analysis of qualitative methods to identify, analyze, and present pattern (theme) in the data. Data reduction in this study uses thematic analysis according to Braun and Clarke. The stages of thematic analysis begin with understanding the data, through making data transcriptions and reading data repeatedly until the preparation of the report, as presented in the Table 1.

Table 1. Stages of Thematic Analysis

\begin{tabular}{|c|c|c|}
\hline No. & Stages & Description of the Process \\
\hline 1. & Understanding data & $\begin{array}{l}\text { Transcription data (if necessary), reading and re-reading data, recording initial } \\
\text { ideas. }\end{array}$ \\
\hline 2. & Generating initial code & $\begin{array}{l}\text { Making code data that has features systematically pulling to all data, compiling } \\
\text { relevant data into each code. }\end{array}$ \\
\hline 3. & Look for themes & $\begin{array}{l}\text { Analyze the code you have and consider how different codes can combine to } \\
\text { form a complete. }\end{array}$ \\
\hline 4. & Theme Review & $\begin{array}{l}\text { Researcher looks at whether the theme supports the data. If the analysis is } \\
\text { incomplete, the researcher needs to review and find what is lacking in the } \\
\text { analysis. }\end{array}$ \\
\hline 5. & $\begin{array}{l}\text { Definition and naming } \\
\text { of themes }\end{array}$ & Creating definitions and naming clearly for each theme. \\
\hline 6. & Compiling reports & $\begin{array}{l}\text { When researchers write reports, must decide which themes make a meaningful } \\
\text { contribution to understanding what is happening in the data. }\end{array}$ \\
\hline
\end{tabular}

2. Presentation of Data

3. Withdrawal Conclusions and Verification

\section{Analysis, Discussions and Findings}

In the BPK Regulation No. 1 of 2007, LHP has the following functions (BPK 2007):

a. Communicating the results of the inspection to the authorities based on applicable laws and regulations.

b. Make examination results avoid misunderstandings.

c. Make examination results avoid misunderstandings.

d. Facilitate follow-up monitoring to determine the effect of corrective actions that should have been used. Audit findings that are part of the BPK audit report are prepared based on developing elements of conditions, 
criteria, effects, and causes. Audit findings submitted by BPK to FETA should be immediately followed up by following the recommendations given by BPK so that financial management is accountable and per under predetermined provisions.

Follow-up on audit findings in general is intended so that the findings can be resolved immediately and to improve financial management in the future so that similar findings do not occur again in the next period. This is in line with the results of researcher interviews with the Inspectorate General of Ministry of Finance which stated that so far the Inspectorate General has been monitoring and overseeing echelon I units within the Ministry of Finance so that the follow-up to BPK recommendations can be completed quickly. And as an effort to prevent the audit findings from happening again, the Inspectorate General has strengthened the organization by forming a new unit namely the Supervision Analysis Subdivision, one of the tasks of which is to analyze the findings and recommendations, so that similar findings are not repeated.

Corrective actions taken by the management of the entity are the implementation of follow-up to the audit findings. The implementation of follow-up on audit findings within FETA is not optimal yet. This is indicated by the fact that the same audit findings in the previous period reappeared in subsequent periods both at the same regional work unit and at different regional work unit within FETA.

\subsection{Factors That Cause Non-Optimal Management of Follow-up Audit Findings in FETA}

From the results of the analysis, six factors cause to non-optimal management of the follow-up of BPK audit findings on FETA. First, there is a lack of commitment from the head of the regional work unit in controlling financial and budget management. The head of the regional work unit in this case, KPA, has a very big influence on the compliance of the employees under his supervision. So even though the commitment of leaders at the highest level is very good, but if not followed by the same commitment at the leadership level below, it will not provide optimal results in achieving goals. In completing the follow-up on the audit findings of the regional work unit, the focus was more on completing responses to the audit findings, while controlling the management of budget activities in subsequent years was considered as business as usual.

Secondly, the lack of human resources competencies in financial management which is their duty and responsibility has an impact on management that is not per under the provisions. Besides, the implementation of mutations and rotation/transfer of employees in the context of employee development sometimes creates new problems in terms of mutations that do not take into account the suitability of officials/employee competencies with duties and functions in their new positions/environments.

Third is standard operating procedures that are not complete, namely the absence of Standard Operating Procedure (SOP) on controlling audit findings so that they do not repeat themselves, and the absence of SOP related to follow-up on audit findings attached to the Polytechnic of State Finance STAN and the Financial Training Center. The steps that have been taken by the center agency are to compile an audit findings matrix as a monitoring tool for the follow-up of the audit findings of the regional work units, but not yet on how to control so that audit findings are not repeated to other regional work units or in the following period.

Fourth, lack of communication to all regional work units and stakeholders, namely the absence of a system for communicating findings and following up on audit results that can accumulate knowledge related to findings and follow-up. Communication is still limited to officials within FETA and several financial managers. Communication has also not been accommodated in the occurrence of replacement of officials/person in charge of activities.

Fifth, namely the lack of optimal implementation of monitoring and evaluation. This is reflected in the monitoring and evaluation activity which is not scheduled between one period and another, different aspects of the monitoring and evaluation subject in each period, and the absence of continuity of monitoring and evaluation activity that is specific to monitoring and evaluating follow-up on audit findings.

Sixth, namely the absence of rule enforcement and integration of employee performance. There was no reward or award given to the regional work unit who had completed the implementation of the audit findings well. As well as punishment, no regional work units by Punish or penalties associated with unresolved follow-up audit findings in the following period.

According to Tague (2005), when we want to identify possible causes of a problem and especially when a team tends to fall into a routine, fishbone diagrams can be used. Fishbone Diagram or fishbone is one of the tools or methods introduced by Dr. Ishikawa in improving quality. This diagram is also called a cause-effect diagram. What is shown in this diagram is an impact or effect of a problem that is accompanied by various causes. The following results are described in the diagram fishbone. 


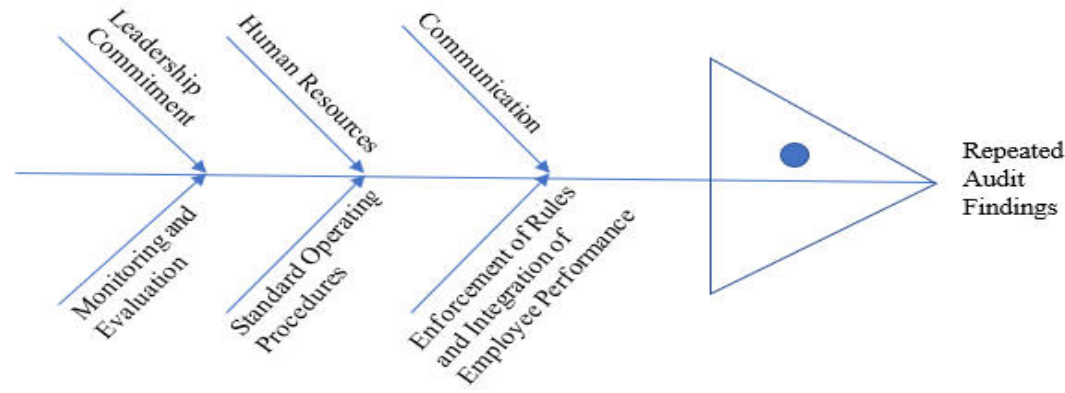

Figure 4.1 Diagram Fishbone

\subsection{Alternative Solutions in Optimizing the Management of Follow-up Audit Findings on FETA}

Against the weaknesses that arise, the researcher tries to identify alternative solutions that can be done by FETA in optimizing the management of follow-up on audit findings that are expected to minimize the occurrence of the same audit findings in future periods, as follows:

a. Increase the commitment and awareness of leaders at the regional work unit level to exercise control over financial and budget management.

The role of managers (leaders) according to Mintzberg (1973) in Griffin (2004) consists of ten different roles which are divided into three basic categories namely interpersonal (interpersonal), carrier of information (informational), and decision-maker (decisional). In interpersonal roles, managers assume the role of chief figure, leader, and liaison, all of which involve relationships with others. In the role of the giver of information, the manager plays the role of supervisor, disseminator, and spokesperson, all of which involve information processing. Whereas in the role of decision-makers, managers act as initiators of change (entrepreneurs), mediators in handling problems, allocating resources, and as negotiators.

As a manifestation of the commitment of the regional work unit leaders in managing the follow-up on audit findings, it is necessary to have direct interaction in discussing the follow-up on audit findings with officials and employees at each regional work unit. Interaction is carried out through regular meetings held to provide information related to audit findings, both those that occur at the relevant regional work unit and other work units within the IRB, determine corrective and/or preventive actions that must be carried out, divide tasks and responsibilities, as well as supervising the implementation of their respective duties.

b. Improve human resource competencies that are tailored to their respective duties and functions through training, training, workshops, and others, as well as the obligation to organize knowledge sharing from employees/officials who have participated in training, training, workshops.

Human resources are essential for the effective functioning of the organization. HR planning is needed which starts with job analysis and future needs. The organization must also strive to develop HR. Training and development enable employees to carry out their current work effectively and prepare for future work (Griffin, 2004).

Training and development is needed because both the organization and the environment are always changing. The existence of these changes makes the members of the organization must always learn and adjust to these changes. An analysis of training needs is needed by using the following procedures (Hanafi, 2011):

1) Evaluation of achievement.

This procedure is carried out through an evaluation of the achievements of each employee and compared with predetermined standards or targets. Achievement results below the target can indicate the need for training.

2) Analysis of work requirements.

Work specifications require the abilities needed to complete a particular job. If the employee is assigned to complete the task but does not have the ability requirements, then the employee needs training or development.

3) Organizational analysis.

An analysis of the organization's effectiveness in achieving its objectives is carried out. If the organization is not very effective, achievement is lower than the target or goal, then the organization's members need training or development.

4) Human resource survey.

This is done through the submission of managers and employees in the organization regarding the problems encountered in their work, and what actions are needed to resolve the problem. 
c. Improving SOPs and uniforming SOPs that have not yet appeared in certain work units so that they can be used as work guidelines for controlling audit findings and following up on audit findings.

The activity of preparing and implementing standard operating procedures requires the full participation of all elements of the existing apparatus within government institutions. This is based on the reason that the most aware of the conditions that exist in their respective workplaces are the employees themselves who will also have a direct impact of the change. The expected targets for the establishment of standard operating procedures are orderliness in the administration of government, improvement in the process of governance, and improving the quality of services to the community.

d. A knowledge management was made related to audit findings within the IRB which could be in the form of making a manual book on inventory of findings from year to year, types of findings that might arise, how to mitigate the risks, based on the experiences or knowledge of various parties. Besides, the role of information technology can also be enhanced, by creating dashboards/wall rooms for monitoring follow-up on audit findings.

Several factors influence the effectiveness of communication in organizations according to Hanafi (2011), namely formal communication channels, organizational authority structure, work specialization, and information ownership.

Also, based on PermenPAN and RB Number 14 of 2011 that have issued guidelines for implementing a knowledge management program, knowledge management can be made concerning audit findings within the IRB. As mentioned in Permenpan-RB Number 14 of 2011, three basic processes in knowledge management can be carried out, namely:

1) Inventory of the findings that occur and the follow-up conducted (data recording).

2) Such information can be accessed by interested parties manually through books, or by involving the role of information technology.

3) The use of knowledge by related parties, as a basis for decision making and improvement (update) of information based on experience and knowledge that occurs.

e. Monitoring and evaluation that is devoted to monitoring and evaluating follow-up of audit findings with regular frequency so that progress can be analyzed from one period to another and from each work unit. As a form of evaluation, an FGD can also be made that specifically discusses audit findings based on an inventory of findings from year to year, typical occurrence of findings, and recommends how to avoid the same findings.

Activity monitoring(monitoring)as defined in Regulation No. 39 of 2006 is observed in the development of implementation activities, identifies and anticipates problems that arise and/or will arise for action can be taken as early as possible. Whereas evaluation is a series of comparing activities to assess the efficiency, effectiveness, benefits, impacts, and sustainability of an activity.

f. The responsibility for managing the follow-up on audit findings is made as the KPI of the officials / employees concerned so that the enforcement of rules can be applied to encourage better implementation of financial management, as well as the strengthening of the role of the UKI over supervision of the tasks and functions related to the management of follow-up on audit findings.

Laying these tasks and responsibilities on the employee KPI will facilitate the application of systems reward and punishment so that the enforcement of the rules can be carried out properly.

\section{Conclusions, Limitation, and Recommendations}

This study was conducted to identify the factors that caused not optimal management of follow-up audit findings at FETA. The audit findings that occurred again in the following years at FETA both the same or different unit in the period 2010 to 2017 indicate that the management of the audit findings has not been optimized. From the results of the study, it can be concluded the following matters:

a. There are six factors that cause the management of audit findings to be not optimal yet in FETA, namely the lack of leadership commitment to the unit, human resource factors, standard operating procedures that are still imperfect, communication factors, monitoring and evaluation that has not been optimal, as well as the enforcement of rules and integration of employee performance.

b. From the six factors, the researcher tries to identify alternative solutions that can be done by FETA in optimizing the management of follow-up on audit findings that are expected to minimize the occurrence of similar audit findings in subsequent periods. The main step in improving the optimization of the management of follow-up on audit findings is through knowledge management and strengthening the role of the Internal Compliance Unit.

In addition, this study contains some limitations as follows:

a. Several informants who have changed positions/positions, so that the possibility of providing answers to interview questions related to the management of follow-up audit findings when the concerned involved has been affected with the current position. 
b. The scope of research is limited to FETA, one unit within the Ministry of Finance..

c. Data reduction is done manually by researchers, not using special software, so it is likely influenced by the limitations of researchers in conducting data reduction.

\section{References}

Adams, MB (1994). Agency Theory and the Internal Audit. Managerial Auditing Journal, Vol. 9 Issue 8 pp. 8-12.

Arens, AA, Randal JE, and Mark SB (2008). Auditing and Assurance Services Integrated Approach. (Issue 12). (Herman Wibowo, Translator). Jakarta: Erlangga.

Ariawan, B. (2011). Strength of the effectiveness of the Recommendations in the Follow-Up to the Examination Results of the Central Java Provincial Audit Board. Jogjakarta: Gajah Mada University.

Arini, IGAAK (2014). Analysis of the Role of Managers in the Follow-Up to Examination Reports by the Internal Audit Unit at Sanglah Hospital Denpasar in 2012. Jakarta: University of Indonesia.

Audit Board of the Republic of Indonesia. (2007). Regulation of the State Audit Board of the Republic of Indonesia Number 01 of 2007 concerning State Financial Auditor Standards.

Audit Board of the Republic of Indonesia. (2010). Regulation of the Republic of Indonesia Financial Examination Agency Number 02 of 2010 concerning Monitoring the Implementation of Follow-Up on Examination Recommendation Results.

Audit Board of the Republic of Indonesia. (2011). Examination Report on the Ministry of Finance's 2010 Financial Report. Jakarta.

Audit Board of the Republic of Indonesia. (2012). Examination Report on the Ministry of Finance's 2011 Financial Report. Jakarta.

Audit Board of the Republic of Indonesia. (2013). Audit Report on the Ministry of Finance's 2012 Financial Reports. Jakarta.

Audit Board of the Republic of Indonesia. (2014). Audit Report on the Ministry of Finance's 2013 Financial Report. Jakarta.

Audit Board of the Republic of Indonesia. (2015a). Audit Report of BPK RI on the 2014 Central Government Financial Statements. Jakarta.

Audit Board of the Republic of Indonesia. (2015b). Ikhtisar Hasil Pemeriksaan Semester I Tahun 2015. Jakarta.

Audit Board of the Republic of Indonesia. (2015c). Laporan Hasil Pemeriksaan Atas Laporan Keuangan Kementerian Keuangan Tahun 2014. Jakarta.

Baidowi, M. (2002). Analisis tindak Lanjut atas Laporan Hasil Pemeriksaan (LHP) : Studi Kasus pada Kantor Badan Pengawas Daerah Kabupaten Jombang. Jogjakarta: Universitas Gajah Mada.

Finance Education and Training Agency. (2010). Laporan Hasil Monitoring dan Evaluasi Pengelolaan Keuangan dan Aset di Lingkungan Badan Pendidikan dan Pelatihan Keuangan.

Finance Education and Training Agency. (2011). Laporan Hasil Monitoring dan Evaluasi Pelaksanaan Anggaran di Lingkungan Badan Pendidikan dan Pelatihan Keuangan Tahun Anggaran 2011.

Finance Education and Training Agency. (2012). Laporan Hasil Monitoring dan Evaluasi Pelaksanaan Anggaran di Lingkungan Badan Pendidikan dan Pelatihan Keuangan Tahun Anggaran 2012.

Finance Education and Training Agency. (2013a). Laporan Hasil Monitoring dan Evaluasi Pelaksanaan Anggaran di Lingkungan Badan Pendidikan dan Pelatihan Keuangan Tahap I Tahun Anggaran 2013.

Finance Education and Training Agency. (2013b). Laporan Hasil Monitoring dan Evaluasi Pelaksanaan Anggaran di Lingkungan Badan Pendidikan dan Pelatihan Keuangan Tahap II Tahun Anggaran 2013.

Finance Education and Training Agency. (2013c). Laporan Hasil Monitoring dan Evaluasi Pelaksanaan Anggaran Pusdiklat/STAN Badan Pendidikan dan Pelatihan Keuangan Tahun Anggaran 2013.

Finance Education and Training Agency. (2014). Laporan Hasil Monitoring dan Evaluasi Pengelolaan Keuangan Negara di Lingkungan Badan Pendidikan dan Pelatihan Keuangan Tahun Anggaran 2014.

Government of Republic of Indonesian. (2003). Undang-undang Nomor 17 Tahun 2003 tentang Keuangan Negara.

Government of Republic of Indonesian. (2004). Undang-undang Nomor 15 Tahun 2004 tentang Pemeriksaan Pengelolaan dan Tanggung Jawab Keuangan Negara.

Government of Republic of Indonesian. (2006a). Undang-undang Nomor 15 Tahun 2006 tentang Badan Pemeriksa Keuangan.

Government of Republic of Indonesian. (2006b). Peraturan Pemerintah Nomor 8 Tahun 2006 tentang Pelaporan Keuangan dan Kinerja Instansi Pemerintah.

Government of Republic of Indonesian. (2006c). Peraturan Pemerintah Nomor 39 Tahun 2006 tentang Tata Cara Pengendalian dan Evaluasi Pelaksanaan Rencana Pembangunan.

Government of Republic of Indonesian. (2008). Peraturan Pemerintah Nomor 60 Tahun 2008 tentang Sistem Pengendalian Intern Pemerintah.

Griffin, RW (2004). Manajemen.(Edisi 7). (Gina Gania, over language). Jakarta: Erlangga.

Hanafi, MM (2011). Manajemen. (Edisi 3). Jogjakarta: Unit Penerbit dan Percetakan Sekolah Tinggi Ilmu 
Manajemen YKPN.

Hartono, T. (2006). Evaluasi Penyelesaian Tindak Lanjut Temuan Audit Sebagai Unsur Penilaian Kinerja Manajemen Kantor Cabang (Studi Kasus pada Bank BTN). Semarang: Universitas Diponegoro.

John, MY, dan Dwi S. (2009). Kiat Memahami Pemeriksaan Laporan Keuangan Pemerintah Daerah di Indonesia. Jakarta: PT. Gramedia Main Library.

Ministry of Finance of The Republic of Indonesia. (2007). Peraturan Menteri Keuangan Nomor 116/PMK.05/2007 tentang Penyusunan Rencana dan Monitoring Penyelesaian Tindak Lanjut Pemerintah terhadap Temuan Pemeriksaan Keuangan oleh Badan Pemeriksa Keuangan atas Laporan Keuangan Kementerian Negara/Lembaga, Laporan Keuangan Bendahara Umum Negara, dan Laporan Keuangan Pemerintah Pusat.

Moleong, LJ (2014). Metodologi Penelitian Kualitatif (Edisi Revisi). Bandung: PT Remaja Rosdakarya.

Murwanto, R., Adi B., dan Fajar HR (2006). Audit Sektor Publik. Suatu Pengantar bagi Pembangunan Akuntabilitas Instansi Pemerintah. Jakarta: Lembaga Pengkajian Keuangan Publik dan Akuntansi Pemerintah (LPKPAP).

Ohiorenoya, John Omogeafe and Ohimai Friday Eboreime. (2014). Knowledge Management Practices and Performance in Nigerian Universities. European Scientific Journal, vol. 10, No. 16 ISSN: 1857-7881.

Rahman, Y. (2010). Analisis Prosedur Audit Pengadaan Barang dan Jasa pada Pemerintah Provinsi Gorontalo : Studi Kasus Dinas Pekerjaan Umum Provinsi Gorontalo. Jogjakarta: Universitas Gajah Mada.

Rai, IGA (2008). Audit Kinerja pada Sektor Publik. Jakarta: Salemba Empat.

Sawyer, LB, Mortimer AD, dan James HS (2005). Audit Internal Sawyer. (Edisi 5). (Desi Adhariani, Penerjemah). Jakarta: Salemba Empat.

Sekaran, UD (2003). Research Methods for Business: A Skill Building Approach. (4th ed). West Sussex: John Wiley \& Sons Ltd.

Sugiyono. (2011). Metode Penelitian Kuantitatif, Kualitatif dan R \& D. Bandung: Alfabeta.

Takeuchi, H., dan Ikujiro N. (2004). Hitotsubashi on Knowledge Management. Singapore: John Wiley \& Sons.

Ulfiyati, Y. dan Christiono U. (2015). Model Teoritis Pengaruh Gaya Kepemimpinan dan Manajemen Pengetahuan pada Keberhasilan Kolaborasi Desain. Jurnal Teknik ITS, vol. 4, No. 1 ISSN: 2337-3539.

Yin, RK (2003). Case Study Research: Design and Methods ( $2^{\text {nd }}$ ed.). Thousand Oaks: Sage Publications. 